\title{
CULTURAL MEANINGS OF HYPERTENSION IN PREGNANCY ACCORDING TO PREGNANT WOMEN ${ }^{1}$
}

\author{
Marialda Martins², Marisa Monticelli ${ }^{3}$ Eliana Diehl ${ }^{4}$
}

\footnotetext{
${ }^{1}$ Paper taken from the thesis - Hypertensive pregnant women: cultural meaning, forms of healthcare and relations to biomedicine, presented to the Postgraduate Nursing Program (PEN) at Universidade Federal de Santa Catarina (UFSC) in 2012. The research received funding from Instituto Nacional de Pesquisa Brasil Plural/CNPq/FAPESC.

2 Ph.D. in Nursing. Adjunct Professor, Nursing Department, Universidade Federal do Paraná. Curitiba, Paraná, Brazil. E-mail: marialda@ufpr.br

${ }^{3}$ Ph.D. in Nursing. Associate Professor, Nursing Department and PEN/UFSC. Florianópolis, Santa Catarina, Brazil. E-mail: marisa@ccs.ufsc.br

${ }^{4}$ Ph.D. in Public Health. Associate Professor, Department of Pharmaceutical Sciences and Postgraduate Program in Pharmaceutical Services at UFSC. Florianópolis, Santa Catarina, Brazil. Email: elianadiehl@hotmail.com
}

\begin{abstract}
Ethnographic study conducted at a teaching hospital (Paraná, Brazil) to understand the cultural meanings pregnant women attribute to the experience of hypertension in pregnancy. The participants were 22 pregnant women, using participant observation and interviews, at the hospital and at their respective homes, between October/2010 and December/2011. The analysis was based on the steps of Ethnonursing. The results showed that the cultural meanings attributed to the hypertension were marked by the fear of the baby's and their own death. They interpreted and gave sense to their experiences based on a net of symbols and meanings created and recreated based on the continuous interlocution with their families, with different social groups and with the health professionals. These women's subjectivity contributed to the diversity of perceptions and meanings. The experience of the illness and the sociocultural references of the pregnant women's context contributed to the comprehension of the cultural meanings, allowing the professionals to attend them based on their specific needs.
\end{abstract}

DESCRIPTORS: Culture. Hypertension, pregnancy-induced. Risk.

\section{SIGNIFICADOS CULTURAIS ATRIBUÍDOS POR GESTANTES À VIVÊNCIA DA HIPERTENSÃO ARTERIAL NA GRAVIDEZ}

RESUMO: Estudo etnográfico realizado em um hospital-escola (Paraná, Brasil), buscando compreender os significados culturais atribuídos por gestantes à vivência da hipertensão arterial na gravidez. Participaram 22 gestantes, por meio de observação participante e entrevistas, tanto no hospital, quanto nos domicílios, entre outubro/2010 e dezembro/2011. Analisou-se segundo os passos da Etnoenfermagem. Os resultados indicaram que os significados culturais atribuídos à hipertensão eram marcados pelo medo da morte do bebê e da própria morte. Elas interpretaram e atribuíram sentidos às suas experiências, tendo por base uma rede de símbolos e significados criada e recriada a partir da interlocução contínua com suas famílias, outros grupos sociais e com profissionais de saúde. A subjetividade dessas mulheres contribuiu à diversidade de percepções e significados. A experiência da doença e as referências socioculturais do contexto das gestantes colaboram para a compreensão dos significados culturais, possibilitando que os profissionais prestem assistência fundamentada nas suas necessidades específicas.

DESCRITORES: Cultura. Hipertensão induzida pela Gravidez. Risco.

\section{SIGNIFICADOS CULTURALES ATRIBUIDOS POR MUJERES EMBARAZADAS A LA VIVENCIA DE HIPERTENSIÓN DURANTE EL EMBARAZO}

RESUMEN: Estudio etnográfico hecho en un hospital-escuela (Paraná, Brasil), que buscó comprender los significados culturales atribuidos por mujeres embarazadas a la vivencia de la hipertensión del embarazo. Participaron 22 mujeres embarazadas por medio de la observación participante y entrevistas, tanto en el hospital como en sus domicilios entre octubre/2010 y diciembre/2011. El análisis fue hecho según los pasos de la Etnoenfermería. Los resultados indicaron que los significados culturales atribuidos a la hipertensión eran marcados por el miedo da la muerte, ya sea de su propia muerte o la del bebé. Ellas interpretaron y atribuyeron sentido a sus experiencias, basadas en una red de símbolos y significados, creada e recreada desde la interlocución continua con sus familias, otros grupos sociales y con los profesionales de la salud. La subjetividad de esas mujeres contribuyó para la diversidad de percepciones y significados. La experiencia de la enfermedad y las referencias socioculturales de su contexto colaboran para comprender los significados culturales, permitiendo a los profesionales que las asistan basados en sus necesidades específicas.

DESCRIPTORES: Cultura. Hipertensión inducida en el embarazo. Riesgo. 


\section{INTRODUCTION}

The Maternal Mortality (MM) ratio is considered an official indicator of any country, as it reveals the quality of the health care offered to women in the pregnancy-puerperal cycle, causing a great impact on the morbidity and mortality conditions of women of fertile age, i.e, between 15 and 49 years. ${ }^{1}$ In 2010, the MM ratio in Brazil corresponded to 68 deaths per 100,000 live births, ${ }^{1}$ a ratio that is considered high, as the World Health Organization establishes a maximum 10 maternal deaths per 100,000 live births as acceptable. ${ }^{2}$ Among these, cases involving hypertensive disorders figure among the most frequent deaths in Brazil, as these were responsible for 13.8 deaths per 100,000 live births in $2010 .^{3}$

When emerging during pregnancy, according to the official health system and in the international context, hypertension is characterized as a risk. This condition puts these women at a physical threshold of double weakness, resulting from the pregnancy process itself and from the overlapping disease, leading to the need for specialized professional care with a view to guaranteeing the control of their pressure levels and, consequently, positive outcomes for mother and child.

Although this care is fundamental from the perspective of avoiding MM, according to official statistics, it is perceived that the obstetric professionals do not always consider these women's subjectivity. The trend in this system is to adopt an ethnocentric posture, without relativizing their specialized knowledge and sometimes even ignoring the local learning and self-care contexts ${ }^{4}$ to attend to their own expectations of coping with the health-disease condition. This reductionism not only devaluates the professional-client interaction, but also does not permit an enhanced view of the health-disease-care process, ${ }^{4-8}$ as the notion of risk these women elaborate may differ from the connotation attributed to risk in the biomedical culture.

In the official health system, epidemiological definitions of risk are predominant, which generally ignore the sociocultural processes. Consequently, the qualitative data, which are decisive to understand the behaviors related to the investigated diseases, ${ }^{7}$ are practically abandoned. This perspective tends to hide the complexity and social dimension of the disease, attributing quantitative, scientific and impersonal characteristics to the risk. Thus, it reduces the social experience to biological aspects and the group to the sum of individuals. ${ }^{7}$
Studies have highlighted ${ }^{6-7}$ that the biomedical logic presupposes the modification of hypertensive pregnant women's behavior, foisting certain attitudes that are justified by the so-called "scientific" knowledge. The professionals' performance generally ignores the women's sociocultural context and aspects related to their subjectivities, ${ }^{6}$ frequently including the idea that they may have different explanations for the occurrence of hypertension. On the other hand, the pregnant women's interpretations of the hypertension experience should be considered, as they can reveal the vulnerabilities to diseases, complications and even death.

Based on the above, it is relevant to deepen the meanings the different groups attribute to the health-disease-care process, ${ }^{5}$ which cannot be dissociated from the cultural context, as culture is a set of symbols and meanings that are shared and make sense in a social system. ${ }^{9}$ In view of this problem situation, this study aimed to understand the cultural meanings pregnant women attribute to the experience of hypertension during pregnancy.

\section{METHOD}

An ethnographic study was developed,, 910 between October 2010 and December 2011, at the High-Risk Prenatal Outpatient Clinic (PNAR) and the Clinical Hospitalization Nursing Ward (EIC) of a teaching hospital in the State of Paraná, which serves as a referral institution for high-risk pregnancy in the South of Brazil, and at the homes of the pregnant women using these services. The PNAR opens from Mondays to Fridays, from 7 a.m. till 4 p.m., attending to high-risk pregnant women who are forwarded from primary health care services in the city and the entire metropolitan region. The EIC is located on the second floor of the maternity hospital, at the Rooming-In Unit, and consists of six beds, where the pregnant women are hospitalized who need direct clinical supervision at any time during the pregnancy.

The key informants were 22 pregnant women. The following inclusion criteria were considered: being diagnosed with pregnancyinduced hypertensive disorder and receiving prenatal care at the outpatient clinic of the PNAR, of any gestational age, or being hospitalized at the EIC at the time of data collection. An additional criterion was being over 18 years of age. The main information collection technique was participant observation, according to the model called observation-participation-reflection, ${ }^{10}$ complemented by semistructured interviews. ${ }^{10-11}$ 
Some pregnant women were observed at the EIC and others at the PNAR, after an agreement with the pregnant women and the consent of the professionals and health students working at the services. At the EIC, the researcher monitored the hospitalized pregnant women at different times of day (morning, afternoon and night), in the attempt to notice what they did and talked about, as well as the relation they established with the health team professionals, particularly focusing on the interactions with the medical and nursing teams. At the PNAR, besides following the medical consultations, the researcher also observed the pregnant women while awaiting care, interacting with them at the waiting room. At their homes, the context of the family relations and the way the pregnant women discussed her health condition with the family were observed.

Among the pregnant women observed, those women were interviewed who accepted to individually talk about the hypertension experience. All interviews were recorded with the women's consent and then transcribed. The interviews were held to complement or deepen the information on themes of relevance for the research, and scheduled in advance at the informants' convenience. Whenever possible, they were held at the women's homes, in neighborhoods in the periphery or metropolitan region of the city where the hospital was located. When this was not possible, the conversations took place at the EIC, at a preset time and at place without interruptions or noise that could interfere in the conversation.

A field diary was used to register and organize the information, by means of interview notes, including the reports themselves, as they were apprehended; observation notes, which corresponded to the detailed description of facts and conversations; theoretical notes, whose contents included the researcher's interpretations on the occasion of the information collection; and methodological notes, which included the observations on the strategies used to collect the information. ${ }^{11}$

The analytic process, based on Ethnonursing, ${ }^{10}$ considered: a) the identification of the main descriptors (common phrases or expressions), looking for indicators of similarity and divergences between the data; $b$ ) the analysis of the context and recurring patterns, considering them as denser analysis units that could contribute to the elaboration of themes) the identification of themes and theoretical formulations.

Approval for the project was obtained from the Research Ethics Committee at the hospital chosen for the research, under n. 2355.249/201010. The premises of National Health Council Resolution 196/96 were complied with and the study subjects signed the Informed Consent Form. In the Results and Discussion section, fictitious names were used to identify the pregnant women, followed by the length of the pregnancy and the place of data collection.

\section{RESULTS AND DISCUSSION}

The 22 informants were between 20 and 45 years old and had between one and six pregnancies. The gestational age varied between 24 and 38 weeks. The mean education level was complete secondary education and the mean family income was three minimum wages. The majority had a fixed job. Concerning religion, seven selfdeclared Evangelical and the remainder Catholic. As regards the marital status, 14 were married, six lived with a fixed partner, one was divorced and one single.

The analytic process resulted in two themes that articulate around the fear of death. The first, focused on the consequences the hypertension can cause for the health of the child who is being born, and the second on the imminence of the woman's own death. The set of these themes reveals the cultural meanings the pregnant women attribute to the hypertension experience in the course of the pregnancy.

\section{"I am afraid because high pressure can cook the baby"}

Due to the establishment or worsening of the hypertension, the women lived with a wide range of feelings. Among these, the most frequently expressed feeling was related to the fear of losing the baby, expressed countless times and at different moments during the fieldwork.

The most difficult of all I think is the fear, controlling the fear, that fear of passing the fifth month, the seventh month, being born prematurely because of the high pressure, of something happening, because I keep on thinking: is he moving? (Priscila, 38 weeks, home).

The fear Priscila expressed was related to the fact that a friend had lost her baby during the fifth month, and her sister-in-law during the seventh month, both of whom had problems due to hypertension.

Priscila and other pregnant women got emotional and cried easily when they referred 
to the child they were expecting, revealing negative emotions and particularly the fear that the baby would not survive until the end of the ninth month. Similar results were found in a study ${ }^{12}$ involving pregnant women with several pregnancy problems that characterized obstetric risk, other than just hypertension, revealing that the women, in their experience of the risk pregnancy, felt feelings like fear, despair, insecurity and guilt, and referred to the fear that the child would not resist.

They told me, my mother and the neighbor, already at the start of pregnancy. The neighbor also had it [pregnancy-induced hypertension]. They said the baby could die in my belly, that pressure in dangerous; and pregnant all the more! You put bad ideas into my head! Ah, I keep on thinking: my God, if the pressure rises, and the baby!! [dramatic tone]. Imagine that you don't know if he's well or not. I calmed down when I did an ultrasound and saw the baby was well. You have to be concerned, right? My neighbor was always asking: 'have you done the ultrasound already?' If I could do an ultrasound each day I would to see if the baby was fine (Maria, 38 weeks, EIC).

Despite these complex feelings, almost all informants expressed that the ultrasound was a moment of relief as, for the entire family, the visual contact with the fetus, triggered very positive reactions, granting the feeling that the baby was truly present, which was sufficient to calm them down during a certain period. ${ }^{13}$

The fear of the baby's death is also influenced by the information that circulates among the women. They seem to share the knowledge about pregnancy and birth, initially in the family context, but also in the small social groups beyond the family. When they hear other women's stories and experience reports, the women configure their own knowledge, thus elaborating the cultural meanings about the pregnancy itself, and also about the risks involved in the occurrence of signs that can threaten it, as revealed by the fact that the baby can "cook" in function of the hypertension.

Over there at the job of [cites a friend's name], there was a woman who, because of the pressure, said her baby almost cooked, like, the whole skin got loose and he died (Sofia, 38 weeks, home). Sofia's mother complements: they also said that at the hospital.

On another occasion, another pregnant woman, with a cautious expression, told the story a neighbor had told her about the baby "cooking": [...] I heard this comment. The neighbor who had it. She said that if the mother has a lot of high blood pressure, the child starts to cook, gets kind of fever [researcher's marks], I don't know, and the child starts to cook inside the mother. That's really serious, right? (Bianca, 27 weeks, home).

Other statements on the theme were obtained, demonstrating the importance of the theme. The women elaborated an explanation, which combines the symptom perceived during the hypertensive crisis with the effects caused on the baby.[...] the heart speeds up and there this heat. Perhaps the baby feels hot too (Sofia, 38 weeks, home); [...] it's because the bag, the fluid in the bag, it boils (Priscila, 38 weeks, home); [...] it seems as if I was going to explode (Ju, 35 weeks, home).

According to the pregnant women, the heat perceived when the blood pressure rises internally warms the body, provoking the temperature increase of the fluid in the bag, which can culminate in the representation of boiling the fetus. Due to this understanding, instead of wanting to preserve the pregnancy, they start to want it to be born, even if prematurely, [...] because they are in better conditions to survive outside than inside the belly (Denise, 28 weeks, EIC). This meaning of risk is paradoxical from a professional perspective, whose behavior is conservative, recommending the extension of the pregnancy, as the neonatal "risk", in situations of maternal hypertension, is the possibility of hypoxia, prematurity and delayed intrauterine growth. ${ }^{14-15}$ To improve the perinatal conditions, the pregnant woman invariably needs to remain hospitalized. ${ }^{16}$ In view of this perception, it was observed that all hospitalized pregnant women felt tense, prolonging their expectation regarding the baby's birth, demonstrating anxiety and often expressing that the waiting was difficult and that they preferred the pregnancy to be interrupted as early as possible.

The women elaborate explanations to give meaning to the events inside their body (tachycardia, headache, dizziness, among others), based on a set of significant symbols, which they create, share and transform, articulating them with the medical knowledge gained at the official institutions (like the possibility of death or fetal syndromes due to the pregnant woman's high blood pressure), which reaffirms the dynamic nature of culture. ${ }^{4-5}$ The bodily transformations the pregnant women experience can affect their self-esteem, self-image and social relationship, as the body is a construction in which different marks are inscribed, in different cultural contexts, which result from distinct interpretive practices. ${ }^{17}$

These perceptions and meanings call into 
question the "virtue" of biological maternity, through the centrality of pregnancy in their own bodies, and the individual responsibility imposed on them in their missions of being pregnant and giving birth, a situation that entails the threat for those who fail in the function of carrying perfect and healthy children. This kind of new meanings entail intense implications in the conceptions and policies surround motherhood, particularly those that value biological aspects. ${ }^{18}$

When perceiving that something is wrong in the evolution of the pregnancy, the women feel frustrated because of the loss of the idealized pregnancy ${ }^{19}$ and feel incapable of playing their role in the reproductive process:

[...] I did not want it to be like that. I get sad. I wanted to be like all women; [...] in the end, I will never have the experience of being a mom like it has to be, like everyone says... (Joana, 31 weeks, EIC).

Hence, the way the hypertensive pregnant women experience the pregnancy and maternity can be analyzed in two senses. On the one hand, the sense relevant to the interaction networks, which influences the women's feeling and acting in this period and, on the other, the women's intrinsic components, which are related to their subjectivity. In that sense, the health professionals should look at the high-risk pregnancy in a broader sense and attempt to understand the great range of meanings constructed, according to each pregnant woman's life experiences and, in that perspective, value each of them in their specific context, shedding light on their needs, valuing their knowledge about the health-disease-care process ${ }^{5}$ and understanding that this knowledge can differ in distinct cultural contexts.

\section{"I know it's dangerous, I'm afraid of dying"}

In general, the pregnant women did not clearly express the fear of death, but it was perceptible that this feeling was present during the pregnancy and, often, was only expressed when the researcher insisted on driving the conversation to explore the woman's fears.

Anyone's afraid, right? Because you're in a very difficult situation. It's normal fear, like anyone in that situation, of happening, right, I don't know [...] (Vera, 27 weeks, EIC).

I'm afraid that something might happen to me (Sofia, 38 weeks, PNAR).

The analysis of 14 studies on pregnancyinduced hypertension ${ }^{20}$ demonstrated that the fear of their own death was the most common feeling the hypertensive pregnant women mentioned. This fear emerged related to very different situations, without the same meaning for all of them. In most cases, the feeling originated in the lack of knowledge about the evolution of the disease and the possibility of leaving other children orphaned, which supports the result found in this study, when the fear of death seemed to be connected to the fear of not being able to take care of the child who was to be born, or even take care of the other children.

[...] afraid of losing her, afraid that something will happen to me too [...] more to her than to me, right? Because when you're a mother, you're much more concerned with the child than with ourselves, right? I don't know, there's so much stuff going through our mind like that (Joaquina, 35weeks, EIC).

The fear of death has also been identified in other studies, as a feeling present in the pregnant women's experience, with different intensity levels, particularly for the pregnant women classified as "high risk" in the obstetric language. ${ }^{19}$

When observing and listening to these women, it was perceived that the fact that they fear for their own life reveals that they experience the risk subjectively or, from a "weak constructionist" ${ }^{\prime 21: 45}$ perspective, that the risks are cultural mediations of danger and actual threats, which gain existence when the social actor perceives it as such. Therefore, the disease is necessarily tied to an experience, and the experience is definitely a dimension of the pregnancy-related hypertension. It refers to the means through which the individuals and social groups respond to a given disease episode, unveiling both social and cognitive, both subject (individual) and objective (collective) risks. ${ }^{22}$ Considering the disease as an experience, a subjective process constructed through sociocultural contexts and experienced by the actors, ${ }^{23}$ it stops being a set of universal physical symptoms observed in an empirical reality and turns into a subjective process in which the bodily experience is mediated by culture.

In this case, the pregnancy-induced hypertension constitutes a subjective process that goes beyond the sensitive world, an interpretation and a judgment about the sensitive impressions the body produces, to which a meaning is attributed, which starts to be considered not as a fact, but as a meaning.

Several informants detailed their previous experiences and some demonstrated that they built 
their own knowledge, capable of granting meaning to their actions and thoughts, and disseminating their meanings in a singular form:

[...] I got afraid that it would come back, because of what had happened in the other pregnancy. We get kind of tense because of what has already happened (Joaquina, 35 weeks, EIC).

[...] ah, my sight was all fuzzy, I had a headache, pain in my neck. It was really scary because I already knew it would happen, because it was the same with the girl. They would put a tube and sulfate. I already knew (Maria, 38 weeks, EIC).

The pregnant women considered the knowledge they gained through their experiences during the current pregnancy important and attempted to relate it with the knowledge gained during the earlier pregnancy. This shows that they interpret the disease experience based on different means, including biomedical knowledge, but always with a private history, as it consists of different experiences. ${ }^{22}$ The pregnant women construct these meanings based on the knowledge obtained in their cultural context, on a range of knowledge, obtained while interacting with relatives, other women and also in the relation with health professionals.

Several women mentioned another form of expressing the danger felt because of the pregnancy-induced hypertension, based on medical information about possible complications:

[...] he [the physician]talked about the preeclampsia, that it's very dangerous, that you can loose either the mother or the child, or both (Priscila, 38 weeks, home).

[...] they [the professionals] say that it's complicated to keep on putting children onto the world like that, because a child whose mother has high blood pressure is a problem for the mother and for the child (Bianca, 24 weeks, home).

Therefore, the data reveal that the explications provided based on the biomedical model influence the construction of meanings, as the pregnant women frequently use adjectives like severe, dangerous, risky, which the professionals commonly use, which permits inferring that the risk the hypertensive pregnant women perceive receives influence from concepts used by the official health system. That is, the word risk became common in the popular language and countless studies have been developed on the term, involving medical "risks", which are related to the health care and treatments. ${ }^{24}$
The pregnant women demonstrated interest in the biomedical knowledge during the visits of the medical team to the nursing wards, when they were attentive, in deep silence, paying attention to everything that was said.

The physician said that the high pressure can cause kidney problems, even when not pregnant, right, if it gets very high and does not get normal, you can have kidney complications, it can affect other organs. Each piece of information I find out, it's more for me to try and take better care of myself (Ângela, 24 weeks, EIC).

The professionals present the "risks" using the technical knowledge of biomedicine, or of the official health system, which is also a cultural system, and which provides these pregnant women with information that is used to interpret their disease. ${ }^{25}$ Thus, the scientific or biomedical knowledge, in which physiological explanations predominate, influences the meanings elaborated based on the pregnant women's cultural experiences. Nevertheless, the way the pregnant women experience the risks depends on their knowledge and the way they feel, which clearly demonstrates that their cultural baggage can support the understanding of the pregnancy risk they experience and drive the measures taken in each specific situation. Therefore, the care the professionals offer should necessarily consider sociocultural aspects and be developed respectfully and free from prejudice. ${ }^{26}$

In a context of plural knowledge and available care forms, subjects or social groups appropriate themselves of and attribute new meanings to parts of other care models that articulate, mix, juxtapose, reconstitute and organize part of these care forms. ${ }^{5}$ In that sense, the subjects their own notion of risk based on the situation experienced, whose meaning is social and historically constructed, and is related to the social value granted in each context. ${ }^{27}$ An example of reorganization and juxtaposition among distinct care forms appears in the testimony of the pregnant woman Júlia:

[...] after the physicians ordered it, I take two pills every six hours each day. I take them with tea. It's two pills of 250 each, that totals 500, right;[...] I boil nine orange seeds when it's very high and, when it isn't, I leave it in a cup and take it. I take tea with the pills, mainly after I felt bad (Júlia, 38 weeks, EIC).

The information obtained from the health professionals represents a very significant influence on the construction of the cultural meanings of pregnancy-induced hypertension, but the hypertensive pregnant women find elements to give 
meaning to their experiences on the Internet and on television as well:

\section{[...] I got frightened, but I saw it on television} too in that soap, you get pregnant, get high blood pressure and die, and there, that's it. I got scared (Ju, 35 weeks, PNAR).

[...] and I also read it on the Internet, I investigated everything. You can see from the blood test if you'll get pre-eclampsia, and the 24-hour blood test, and the swelling on the hands, face and feet. He said [referring to the physician] that if I felt too swollen I should go to the doctor (Priscila, 35 weeks, home).

The television and Internet are identified as the means to disseminate important information in the health area. The Internet can combine different existing information sources, deriving from personal experiences from lay persons and professionals. ${ }^{28}$ Therefore, the different existing viewpoints on a certain theme are expressed, allowing the pregnant women access to information compatible with different cultural models.

\section{FINAL CONSIDERATIONS}

The cultural meanings the pregnant women attribute to the hypertension are marked by the fear of the baby's and their own death. The women do not always refer to the term risk, but it is observed that they all experience this condition when they reveal the feelings experienced, and interpret the "risk" as the possibility that something tragic will happen.

The fear of their own death demonstrates that the pregnant women are aware that they are in danger, although not referring to this feeling directly in most cases. They suggest that this feeling is based on the cultural construction of the maternal role, which rests on the female body's ability to generate and give birth to healthy individuals, making the women responsible for their own and their children's lives, besides putting the status of the woman-mother in the social context at "risk".

The probability of hypertension causing the baby's death by "cooking" and the desire for birth to happen as soon as possible indicate that, in the pregnant women's cultural context, there are explanations for the problem that differ from the biomedical ones, which the professionals should know with a view to a symmetrical dialogue. In addition, the health team needs to take this perception seriously, as the difficulty to await the term or maturing of the fetus can further increase the anxiety and, consequently, the pressure levels, besides making a fuller experience of motherhood impossible.

In general, this system of meanings finds support in the notions of gender, body, reproduction and the way of exercising the maternal social role. These findings indicate the need for the professionals to create ethnographic spaces with the pregnant women and their families, where they can discuss their experiences, using the dialogue as a care strategy, as well as the approximation between the pregnant women's and the biomedical cultural system.

In the model established in society, the professional knows, while the patient is attributed with a profound lack of knowledge. Some professionals do not know (or devaluate) the patients and family members' conceptions and practices, highlighting the lack of dialogue and the disregard for the subjects' knowledge and experience.

The subjectivity contributes to the range of perceptions and meanings manifested, considering that these women's individual aspects differ from the obstetric perceptions. Thus, the experience is one of the dimensions of the disease that should be considered, as it contains the singularity and meaning that will underlie the start of a fruitful relationship, for the health professionals as well as the system user. Unveiling these meanings can support the health services, so that the professionals can go beyond technical care, including the sociocultural references of the hypertensive pregnant women's context in care delivery. Thus, they can be granted with a healthier experience, contributing to a change in the reality of maternal mortality.

The results presented here reveal indicators of the importance of studies that explore this phenomenon, considering the cultural contexts of the pregnant women who experience hypertensive disorders. Nevertheless, some limitations should be mentioned. These include the lack of publications on the theme, in Brazil and abroad, which in a way limited the discussion of the ethnographic data in confrontation with the literature, as well as the interpretation of the cultural meanings.

This paper contributes to highlight the lack of knowledge on the cultural meanings these women attribute to the health-disease process. In addition, the understanding of the cultural meanings of pregnancy-induced hypertension can contribute to a further approximation between professionals and pregnant women, and allow the services to attend to these women's expectations and projects, in view 
of the complexity of the experience and the countless feelings that flourish when experiencing the pregnancy with hypertension. This understanding will allow the professionals to deliver more specific care and more humanized to these women, in line with the current health policies, besides favoring the enhancement of the "risk" concept.

\section{REFERENCES}

1. Ministério da Saúde (BR) [página na internet]. Brasília (DF): MS, 2012. Secretaria de Vigilância em Saúde. Boletim1 [acesso2012 Dez 18]. Disponível em: http:/ / portalsaude.saude.gov.br/portalsaude/ index.cfm?portal=pagina.visualizarTexto\&codCo nteudo $=6403 \& \operatorname{codModuloArea}=783 \&$ chamada $=b$ oletim-1/2012-_-mortalidade-materna-no- $\% 20 \% 20$ brasil

2. World Health Organization. Trends in maternal mortality: estimates developed by WHO, UNICEF, UNFPA and The World Bank 1990 to 2008.Geneva (SW): World Health Organization; 2010.

3. Ministério da Saúde (BR) [página da internet]. DATASUS. Sistema de Informação sobre Mortalidade-SIM 2011 [acesso 2011 Out 7]. Disponível em: http:/ / tabnet.datasus.gov.br

4. Menéndez EL. Modelos de atención de los padecimientos: de exclusiones teóricas y articulaciones prácticas.Ciênc Saúde Coletiva. 2003; 8(1):185-206.

5. Menéndez EL. Estilos de vida, risco e construção social. In: Menéndez EL. Sujeitos, saber e estrutura: uma introdução ao enfoque relacional no estudo da saúde coletiva. São Paulo (SP): Hucitec; 2009. p.71-138.

6. Duarte LFD. Indivíduo e pessoa na experiência da saúde e da doença. Ciênc Saúde Coletiva.2003;8(1):173-83.

7. Taussing M. The nervous system. New York (US): Routledge; 1992.

8. Castiel LD. A medida do possível: saúde, risco e tecnobiociências. Rio de Janeiro (RJ): Fiocruz; 1999.

9. Geertz C. A interpretação das culturas. Rio de Janeiro (RJ): LTC; 2008.

10. Leininger $\mathrm{M}, \mathrm{McF}$ arland $\mathrm{M}$. Culture care and diversity: a worldwide nursing theory. $2^{\mathrm{a}} \mathrm{ed}$. Boston (US): Jones and Bartlett Publishers; 2006.

11. Shatzman L, Strauss AL. Field research: strategies for a natural sociology. New Jersey (US): PrivitiveHall, 1973.

12. Cunha EFC, Carvalho MMSB, Santos CA, Ferreira EL, Barros MMS, Mendonça ACM. Aspectos socioemocionais de mães de bebês prematuros. Psicol Foco. 2009 Jul-Dez; 3(2):35-43.

13. Rodrigues DRS, Franco EL, Kosac KF, Franco LLMM, Silveira MMM, Usevícious PMA. Relatos orais e reflexões sobre a experiência da gestação e construção do bebê imaginário. Indagatio Didactica. 2013; 5(esp):978-88.

14. Chaim SRP, Oliveira SMJV, Kimura AF. Hipertensão arterial na gestação e condições neonatais ao nascimento. Acta Paul Enferm. 2008 Jan-Mar; 21(1);53-8.

15. Vettore MV, Dias M, Domingues RMSM, Vettore MV, Leal MC. Cuidados pré-natais e avaliação do manejo da hipertensão arterial em gestantes no SUS no município do Rio de Janeiro, Brasil. Cad Saúde Pública. 2011 Mai; 27(5);1021-34.

16. Neto CN, Souza ASR, Amorim MMR. Tratamento da pré-eclâmpsia baseado em evidências. Rev Bras Ginecol Obstet. 2010 Set; 32(9):459-68.

17. Gualda DMR, Praça NS, Merighi MAB, Hoga LAK, Bergamasco RB, Salim NR, et al. O corpo e a saúde da mulher. Rev Esc Enferm USP [online]. 2009 Dez [acesso 2012 Fev 19]; 43(2):1320-5. Disponível em: http://www.scielo.br/pdf/reeusp/v43nspe2/ a30v43s2.pdf

18. Odent M. Cientificação do amor. Florianópolis (SC): Saint Germain; 2002.

19. Souza JP, Cecatti JG, Parpinelli MA, Krupa F, Osis MJ. An emerging "maternal near miss syndrome" narratives of women who almost died during pregnancy and childbirth. Birth. 2009 Jun; 36(2):14957.

20. Martins M, Monticelli M, Brüggemann OM, Costa R.A produção de conhecimento sobre hipertensão gestacional na pós-graduação stricto sensu da enfermagem brasileira. Rev Esc Enferm USP. 2012 Ago; 46(4):802-8.

21. Castiel LD, Guilam MCR, Ferreira MS. Correndo o risco: uma introdução aos riscos em saúde. Rio de Janeiro (RJ): Fiocruz; 2010.

22. Alves PCA. Experiência da enfermidade: considerações teóricas. Cad Saúde Pública. 1993JulSet; 9(3):263-71.

23. Langdon EJ. A doença como experiência: a construção da doença e seu desafio para a prática médica. Antropol Prim Mão. 1996:1-23.

24. Lupton D. Risk. London (UK): Routlege; 2004.

25. Langdon EJ. Cultura e os processos de saúde e doença. In: Anais do IV Seminário sobre Cultura, Saúde e Doença, 2003, Out 13-16; Londrina, Brasil. Londrina (PR): Programa das Nações Unidas para o Desenvolvimento; 2003.

26. Siqueira KM, Barbosa MA, Brasil VV, Oliveira LMC, Andraus LMS. Crenças populares referentes à saúde: apropriação de saberes sócio-culturais.Texto Contexto Enferm [online].2006 Jan-Mar [acesso 2013 Mar 12]; 15(1):68-73. Disponível em: http:/ / www. scielo.br/pdf/tce/v15n1/a08v15n1.pdf

27. Douglas M. Risk and blame: essays in cultural theory. Londres (UK): Routledge; 1994. 
28. Ybarra M, Suman M. Reasons, assessments and actions taken: sem and age differents in uses of internet health information. Health Educ Research [online]. 2008 [acesso2013 Out 31]; 23(3):512-21. Available from: http://her.oxfordjounarls.org/ content/23/3/512.full.pdf + html 